\title{
Effect of Broiler Breeder Age on Pancreas Enzymes Activity and Digestive Tract Weight of Embryos and Chicks
}

\section{Author(s)}

Maiorka A

Santin $\mathrm{E}^{1}$

Silva AVF

Routman $\mathrm{KS}^{2}$

Pizauro Jr. JM²

Macari $\mathrm{M}^{2}$

Universidade Federal do Paraná - UFPR.

Faculdade de Ciências Agrárias e Veterinárias - Unesp.

\section{Mail Address}

Alex Maiorka

Universidade Federal do Paraná

Setor de Ciências Agrárias

Departamento de Zootecnia

Rua dos Funcionários, 1540

80.035-050 - Curitiba, PR.

E-mail: amaiorka@ufpr.br

\section{Keywords}

Broiler breeder age, embryo, enzymatic activity, gastrointestinal tract.

\section{Acknowledgements}

The authors thank Fundação de Amparo à Pesquisa do Estado de São Paulo (FAPESP) for financial support - Proc. 98/11304-9.
Arrived: april / 2003

Approved: february / 2004

\section{ABSTRACT}

A study was carried out to evaluate the effect of broiler breeder age on the development of the digestive tract of embryos and chicks. Fertilized eggs Cobb from 30 and 60 week-old broiler breeder was utilized in this experiment. The results showed that eggs from older (60 weeks of age) broiler breeders were heavier $(p=0.001)$ than those from younger (30 weeks of age) broiler breeder. In addition, older broiler breeder had larger $(p=0.001)$ embryos showing a higher yolk sac $(p=0.001)$ and higher gastrointestinal tract relative weight $(p=0.007)$ than those from younger broiler breeder. The activities of pancreatic lipase and trypsin enzymes were also higher in embryos from older broiler breeder than those from younger broiler breeder ( $p=0.001$ and $p=0.002$, respectively). Nevertheless, at the seven-day-old chick, no difference was observed in relative weight of gastrointestinal tract or pancreatic lipase and trypsin activities between older and younger broiler breeder age. However chicks from older broiler breeder were heavier than those from younger broiler breeder $(p=0.005)$. These data suggest that broiler breeder age is important on grower and on the development of the gastrointestinal tract and pancreatic lipase and trypsin activities of embryo. However after one week of hatching the morphophysiological difference disappear.

\section{INTRODUCTION}

As the broiler breeder ages, it produces bigger ovarian follicles, which results in larger eggs with larger yolks. Therefore, eggs from older broiler breeders are heavier than those from younger broiler breeders. The increase in ovulation intervals is followed by an increase in egg size, as the same amount of yolk from hepatic synthesis is added to a lower number of follicles (Zakaria et al., 1983). There is a high correlation between egg weight and chick weight at hatching (Wilson, 1991).

Broiler breeder age also influences the time of incubation. Mather \& Laughlin (1979) showed that eggs from older broiler breeders hatch first than those from younger broiler breeders, and this could be related to embryo development.

Brake (1995) suggested that the higher level of protein in diet of younger broiler breeders results in thicker albumen, which decreases oxygen exchange, and also yolk sac absorption by the embryo. According with this author, $90 \%$ of the embryo energy comes from the oxidation of fatty acids, and low oxygen could delay this process and also the embryo development.

Some studies (Applegate et al., 1999; Applegate \& Lilburn, 1999) also showed differences in intestinal morphology between the embryo phase and after-embryo phase in chicks derived from broiler breeders of different ages. Turkeys poults from older breeders had higher villi height 
Maiorka A, Santin E, Silva AVF, Routman KS, Pizauro Jr. JM, Macari M and higher capacity of metabolize glucose than poults from younger breeders, which suggests that birds from younger breeders are not fully adapted to the metabolic changes caused by post-hatching feed.

In this context, the objective of this study was to evaluate the effect of broiler breeder age on the weight of the organs of the gastrointestinal tract and enzymatic activity of pancreas in embryos at 20 days of incubation and seven-day-old chicks.

\section{MATERIAL AND METHODS}

Fertilized eggs from 30-week-old and 60-week-old Cobb-500 ${ }^{\mathrm{TM}}$ broiler breeders were incubated at 37.8 ${ }^{\circ} \mathrm{C}$ and $60 \%$ moisture. On day 20 of incubation, 25 embryos of each broiler breeder age were sacrificed and gizzard + proventriculus + intestines, yolk sac, liver were weighed. The weight of each organ was expressed in absolute ( $\mathrm{g}$ ) and relative weight (\%) of embryo weight. The pancreas of 30 embryos was also collected in order to evaluate enzymatic activity, with a pool of six pancreas as one experimental unit.

At hatching, chicks from broiler breeders of different ages ( 25 chicks from 30-week-old breeders and 25 chicks from 60-week-old broiler breeders) were weighed and placed in battery pens, and received water and feed (the diet was based on corn and soybean meal with $2,900 \mathrm{kcal} \mathrm{ME} / \mathrm{kg}$ and $22 \%$ crude protein) $a d$ libitum. At seven day of age, ten chicks ( 5 from each broiler breeder age) were weighed, sacrificed and gizzard + proventriculus, liver, pancreas, intestine and yolk sac were weighed. The weight of each organ was expressed in absolute (g) and relative weight (\%) of chick weight. The pancreas was collected to evaluate enzyme activity, with each pancreas as one experimental unit.

The pancreas tissue were immediately frozen in liquid nitrogen and stored at $-70^{\circ} \mathrm{C}$ freezer for analyses.

\section{Enzymatic assay}

Pancreas was homogenized in Ultra-Turrax in 500 $\mathrm{mM}$ Tris- $\mathrm{HCl}$ buffer containing $50 \mathrm{mM} \mathrm{CaCl}{ }_{2}(1: 20 \mathrm{w} /$ v), $\mathrm{pH} 8.0$, at $4^{\circ} \mathrm{C}$. Homogenate was centrifuged under refrigeration $\left(4^{\circ} \mathrm{C}\right)$ at $14,000 \times \mathrm{g}$ for 30 minutes. An aliquot of pancreatic supernatant was used for immediate lipase determination and remaining supernatant was frozen in liquid nitrogen and stored at $-70^{\circ} \mathrm{C}$ freezer until determination of activity of the other enzymes.

Pancreatic lipase activity was assessed by titration (Tietz \& Fiereck, 1966), using the olive oil emulsion $\left(\mathrm{SIGMA}^{\circledR}\right)$ as substrate. The co-lipase used in this study
Effect of Broiler Breeder Age on Pancreas Enzymes Activity and Digestive Tract Weight of Embryos and Chicks

was obtained from poultry pancreas. One unit of enzymatic activity was defined and expressed as the quantity of enzyme that release one mmol of fatty acid per minute.

Activation of pancreatic trypsinogen was accomplished by pre-incubation period with 0.08 units of Enterokinase $\left(\mathrm{SIGMA}^{\circledR}\right)$ for 30 minutes. After the activation, the trypsin activity was determined at $37^{\circ} \mathrm{C}$ in accordance with described by Kakade et al. (1974) using N-a-benzoyl-L-arginine-p-nitroanilide (L-BApNA, SIGMA ${ }^{\circledR}$ ) as substrate. One unit of enzyme activity was defined and expressed as the quantity of enzyme that release one $\mathrm{mmol}$ of $\mathrm{p}$-nitroanilide/min, at $37^{\circ} \mathrm{C}$.

Protein concentration was determined by the procedure of Hartree (1972) using bovine serum albumin as standard.

\section{Statistical Analysis}

The randomized experimental design was used, with 25 replicates for egg, embryo, proventriculus+gizzard, small intestine, liver, yolk sac and weight of chicks at hatching. For enzymatic activity 5 replicates of each experimental unit of pancreas were utilized. Data were analyzed by analysis of variance, using the General Linear Model (GLM) procedure of SAS (1998). A normality test was carried out to ensure that percentage values were similar in variance $(p>0,05)$.

\section{RESULTS AND DISCUSSION}

Organ weight results from embryos at 20 days of incubation are shown in Table 1. Except for absolute weight of the gastrointestinal tract and relative liver weight, all the results were affected by broiler breeder age. Vieira \& Moran (1998) observed that the broiler breeder age influenced the development of many chicks organs after hatching. In addition, heavier embryos and yolk sacs were seen in eggs from older broiler breeders than eggs from young broiler breeders in the last week of incubation (Maiorka et al., 2000). It was also reported that broiler breeder age also influenced the development of the intestinal tract of these birds after hatching.

The activity of pancreatic enzymes of embryos is shown in Table 2. The results showed higher lipase and trypsin activities in embryos from older broiler breeders as compared to those from younger broiler breeders, which suggest that broiler breeder age affect morphology and physiology development of the intestinal tract during incubation.

The specific activities of carboxypeptidase $A$ and chemotrypsin increase progressively from $16^{\text {th }}$ day of 
Maiorka A, Santin E, Silva AVF, Routman KS, Pizauro Jr. JM,

Effect of Broiler Breeder Age on Pancreas Enzymes Activity and Digestive Tract Weight of Embryos and Chicks
Table 1 - Broiler breeder age on viscera and embryos weight at 20 days of incubation, chicks weight at hatching and viscera and chick weight at 7 days of the age.

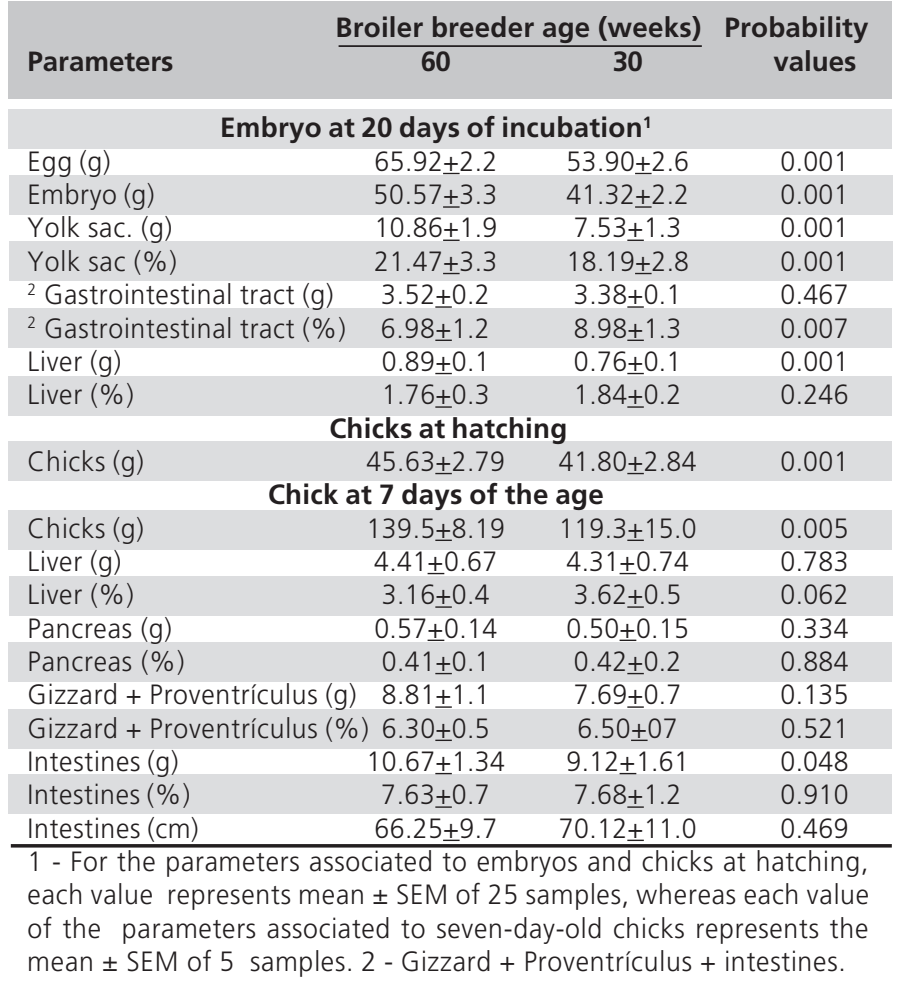

Table 2 - Broiler breeder age on pancreas enzymes activities (lipase ${ }^{+}$and trypsin*) of embryos at 20 days of incubation and chicks at 7 days of the age.

\begin{tabular}{|c|c|c|c|}
\hline \multirow[t]{2}{*}{ Enzymes $^{2}$} & \multicolumn{2}{|c|}{ Broiler breeder age (weeks) } & \multirow{2}{*}{$\begin{array}{c}\text { Probability } \\
\text { values }\end{array}$} \\
\hline & 60 & 30 & \\
\hline \multicolumn{4}{|c|}{ Embryo at 20 days of incubation ${ }^{1}$} \\
\hline Lipase & $0.171 \pm 0,02$ & $0.101 \pm 0.03$ & 0.001 \\
\hline Trypsin & $3.32 \pm 0.66$ & $2.34 \pm 0.34$ & 0.002 \\
\hline \multicolumn{4}{|c|}{ Chicks at 7 days of age } \\
\hline Lipase & $10.71 \pm 1.77$ & $9.07 \pm 1.44$ & 0.653 \\
\hline Trypsin & $33.84 \pm 10.80$ & $34.33 \pm 11.06$ & 0.498 \\
\hline
\end{tabular}

incubation until the second day post-hatching as reported by Kulka \& Duskin, (1964) and Marchaim \& Kulka, (1967). Escribano et al. (1988) observed that lipase activity on yolk sac membrane of turkey embryos was present on the $7^{\text {th }}$ day of incubation, and that this activity increased until hatching, but reducing after 4 days of life. The opposite occurred with pancreatic lipase activity, which increased linearly up to the $16^{\text {th }}$ day after hatching. According to Mather \& Laughlin (1979), broiler breeder age influences the duration of incubation, and this could be related to the higher development of the embryo during the first two days of incubation.

Embryos from older broiler breeders have larger yolk sacs, which induce higher specific activity of some enzymes, as enzyme activity is dependent on the presence of substrate.

In the present study, chicks from older broiler breeders were heavier $(p=0.001)$ than those from younger broiler breeders. However, at seven days of age, no differences were observed in organ weight or enzyme activity between chicks coming from different broiler breeder. Applegate et al. (1999) observe that, at hatching, embryos from older broiler breeders showed faster development of intestinal mucosa. However, did not observe any differences in the intestinal mucosa of chicks from different broiler breeder ages after feeding.

Chicks body weight in the present experiment was influenced by broiler breeder age $(p=0.005)$. Chicks from older broiler breeders were $20.2 \mathrm{~g}$ heavier than those from younger broiler breeders at 7 days of life (Table 1), suggesting that for each $1 \mathrm{~g}$ of weight difference at hatching, there is a $5.25 \mathrm{~g}$ weight difference at seven day of age. Gonzales et al. (1994) and Vieira \& Moran (1998) asserted that body weight difference at hatching, caused for broiler breeder age, increases with the age of broiler.

\section{CONCLUSIONS}

Broiler breeder age influenced visceral development, as well enzymes activity of the pancreas during embryonic phase. Embryos from older broiler breeders had higher intestinal tract development as compared to those from younger broiler breeders.

At seven day of age, viscera size and enzyme activity of broilers from broiler breeders of different ages were not different.

\section{REFERENCES}

Applegate TJ, Dibner JJ, Kitchell ML, Uni Z, Lilburn MS. Effect of turkey (Meleagridis gallopavo) breeder hen age and egg size on poult development. 2. Intestinal villus growth, enterocyte migration and proliferation of the turkey poult. Comparative Biochemistry and Physiology B 1999; 124:381-389.

Applegate TJ, Lilburn MS. Effect of turkey (Meleagridis gallopavo) breeder hen age and egg size on poult development. 1. Intestinal growth and glucose tolerance of the turkey poult. Comparative Biochemistry and Physiology B 1999; 124:371-380. 
Brake JT. Pontos importantes de manejo no incubatório para uma boa eclosão. In: Conferência Apinco'95 de Ciência e Tecnologia Avícolas; 1995; Anais. Curitiba-PR, Brasil. p.33-50.

Escribano F, Rahn BE, Sell J. Development of lipase activity in yolk membrane and pancreas of young turkeys. Poultry Science 1988; 67:1089-1097.

Gonzales E, Junqueira OM, Macari M, Andreatti RL, Mendes AA. Influência da idade de produção da matriz na incidência da síndrome da morte súbita em frangos de corte. Revista da Sociedade Brasileira de Zootecnia 1994; 23:243-248.

Hartree EF. Determination of protein. A modification of the Lowry method that gives a linear photometric response. Analytical Biochemistry 1972; 48:422-427.

Kakade ML, Rackis JJ, Mcghee JG. Determination of trypsin inhibitor activity of soy products: A collaborative analysis of an improved procedure. Cereal Chemistry 1974; 51:376-382.

Kulka RG, Duskin U. Patterns of growth and amylase activity in the developing chick pancreas. Biochemica et Biophysica Acta 1964; 91:506-514.

Maiorka A, Santin E, Silva, AVF, Bruno LDG, Boleli IC, Macari M. Desenvolvimento do trato gastrointestinal de embriões oriundos de matrizes pesadas de 30 e 60 semanas de idade. Revista Brasileira de Ciência Avícola 2000; 2:141-148.

Marchaim U, Kulka, RG. The non-paralel increase of amylases, chymiotrypsinogen and procarboxypeptidase in the developing chick pancreas. Biochemica et Biophysica Acta 1967; 146:553-559.

Mather CM, Laughlin KF. Storage of hatching eggs: the interaction between parental age and early embryonic development. British Poultry Science 1979; 20:595-604.

SAS Institute. SAS ${ }^{\circledR}$ (Statistical Analysis System). User's Guide: Statistics. Cary, NC: SAS Institute Inc., 1998.

Tietz MW, Fiereck EA. A specific method for serum lipase determination. Clinica Chimica Acta 1966; 13:352-358.

Vieira SL, Moran Jr. ET. Eggs and chicks from broiler breeders of extremely different age. Journal of Applied Poultry Research 1998; 7:372-376.

Wilson HR. Interrelations of egg size, chick size, posthatching growth and hatchability. World's Poultry Science Journal 1991; 47:5-20.

Zakaria AH, Miyaki T, Imai K. the effect of aging on ovarian follicular growth in laying hens. Poultry Science 1983; 62:670-674. 